Zeszyty Naukowe Szkoły Głównej Gospodarstwa Wiejskiego w Warszawie

Problemy Rolnictwa Światowego tom 18 (XXXIII), zeszyt 1, 2018: 149-158

DOI: $10.22630 /$ PRS.2018.18.1.14

Piotr Misztal

Uniwersytet Jana Kochanowskiego w Kielcach

\title{
Globalna nierównowaga finansowa we współczesnej gospodarce światowej
}

\section{Global financial imbalance in the contemporary world economy}

\begin{abstract}
Synopsis. Celem niniejszego artykułu jest określenie skali zjawiska globalnej nierównowagi finansowej w krajach o różnym poziomie rozwoju gospodarczego oraz wskazanie głównych czynników determinujących to zjawisko. W pracy wykorzystano metodę badawczą opartą na studiach literaturowych z zakresu finansów międzynarodowych i międzynarodowych stosunków gospodarczych. W szczególności wykorzystano bogatą literaturę obcojęzyczną oraz publikacje polskojęzyczne dotyczące analizowanej tematyki. Wszelkie dane statystyczne wykorzystane w pracy pochodzą z bazy statystycznej Międzynarodowego Funduszu Walutowego (International Monetary Fund). Na podstawie przeprowadzonych badań literaturowych, stwierdzono, że do najważniejszych determinant tego zjawiska można zaliczyć nadwyżkę globalnych oszczędności, prowadzoną politykę merkantylistyczną w krajach Azji Wschodniej oraz zaburzenia na międzynarodowych rynkach finansowych. Wyniki przeprowadzonych badań mają ogromne znaczenie w szczególności z makroekonomicznego punktu widzenia, gdyż rosnące nadwyżki lub deficyty na rachunkach obrotów bieżących wywołują chroniczne nadwyżki lub deficyty w budżetach krajowych poprzez tzw. efekt deficytów bliźniaczych. Dodatkowo nierównowagi na rachunkach obrotów bieżących wpływają na międzynarodową pozycję konkurencyjną gospodarek, ceny towarów, usług, walut i czynników produkcji.
\end{abstract}

Słowa kluczowe: bilans obrotów bieżących, globalizacja, gospodarka światowa

\begin{abstract}
The aim of this article is to assess the scale of global financial imbalance in countries with different levels of economic development, and to identify the main determinants of this phenomenon. In the paper, a research method based on literature studies in the field of international finance and international economics is used. In particular, rich foreign-language literature and Polish-language publications related to the analyzed subject were used. All statistical data used in the work comes from the International Monetary Fund's statistical database. Based on the literature, it has been found that the most important determinants of this phenomenon are surplus of global savings, mercantilism in East Asia and disturbances in international financial markets. The results of these studies have great importance, in particular from a macroeconomic point of view, as rising surpluses or current account deficits cause chronic surpluses or deficits in national budgets through the so-called twin deficits effect. In addition, current account imbalances affect the international competitive position of economies, prices of goods, services, currencies and production factors.
\end{abstract}

Keywords: current account, globalization, world economy

JEL Classification: F32, F41, F62

\section{Wprowadzenie}

Globalna nierównowaga finansowa jest istotnym zagadnieniem w toczacej się od wielu lat dyskusji nad skutkami postępującego procesu globalizacji, przy czym poglądy

${ }^{1}$ dr hab., prof. nadzw., Wydział Prawa, Administracji i Zarządzania UJK w Kielcach, e-mail: pmisztal@ujk.edu.pl 
dotyczące globalnej nierównowagi finansowej istotnie ewoluowały w ostatnim okresie. Początkowo analiza i dyskusja koncentrowały się na deficycie na rachunku obrotów bieżących Stanów Zjednoczonych. Następnie analizę tą rozszerzono i uwzględniono również zmiany nadwyżki $w$ bilansach obrotów bieżących, przede wszystkim w krajach azjatyckich i gospodarkach eksportujących ropę naftową. Natomiast obecnie zasadne wydaje się uwzględnienie w dyskusji zmian struktury tego zjawiska wśród krajów rozwiniętych gospodarczo oraz krajów transformujących się i rozwijających.

Celem niniejszego artykułu jest określenie skali zjawiska globalnej nierównowagi finansowej $\mathrm{w}$ krajach o różnym poziomie rozwoju gospodarczego oraz wskazanie głównych czynników determinujących to zjawisko. W pracy wykorzystano metodę badawczą opartą na studiach literaturowych z zakresu finansów międzynarodowych i międzynarodowych stosunków gospodarczych. W szczególności wykorzystano bogatą literaturę obcojęzyczną oraz publikacje polskojęzyczne dotyczące analizowanej tematyki. Wszelkie dane statystyczne wykorzystane $\mathrm{w}$ pracy pochodzą $\mathrm{z}$ bazy statystycznej Międzynarodowego Funduszu Walutowego (International Monetary Fund - IMF).

\section{Istota problemu globalnej nierównowagi finansowej}

W niniejszym opracowaniu próbuje się wyjaśnić zjawisko globalnej nierównowagi finansowej definiowane, jako rosnące nierównowagi między krajami w odniesieniu do sald i ich rozmiarów na rachunkach obrotów bieżących bilansu płatniczego. Problem globalnej nierównowagi jest szczególnie widoczny od końca lat 90. XX wieku, kiedy to koncentrowano swoje uwagi na przyczynach i konsekwencjach pogłębiających się deficytów i nadwyżek na rachunkach obrotów bieżących w krajach o różnym poziomie rozwoju gospodarczego. Kwestia dotycząca sald bilansów obrotów bieżących jest interesująca w szczególności z ekonomicznego punktu widzenia, tym bardziej, że sytuacji tej nie są w stanie w pełni wyjaśnić żadne standardowe teorie ekonomiczne.

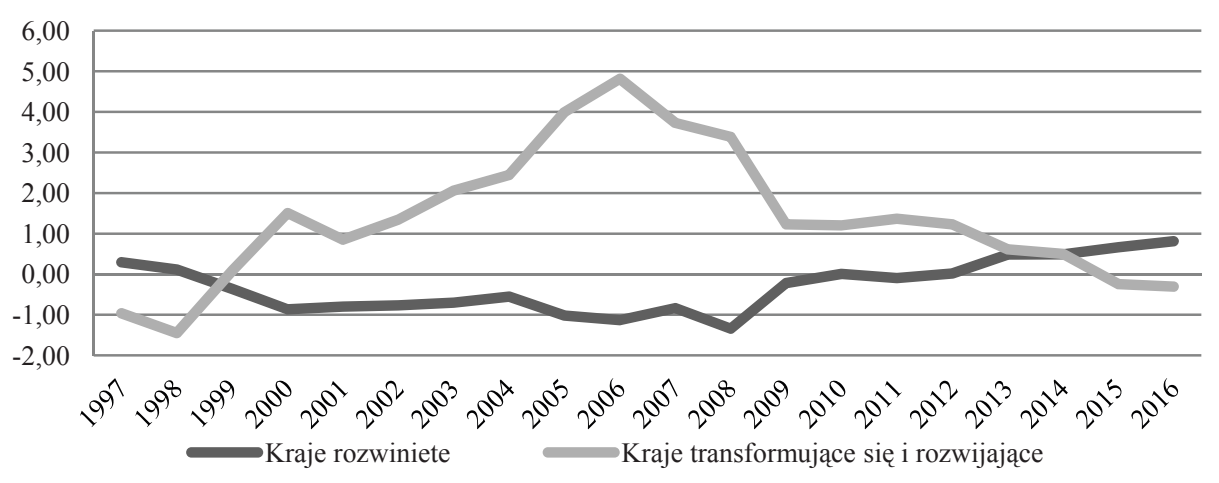

Rys. 1. Udział salda bilansu obrotów bieżących w PKB w krajach o różnym poziomie rozwoju gospodarczego w okresie 1997-2016 (w \%)

Fig. 1. Share of current account balance in GDP in countries with different levels of economic development in the period 1997-2016 (in\%)

Źródło: opracowanie własne na podstawie (World Economic Outlook, 2017). 
Zgodnie z rysunkiem 1, do końca lat 90. XX wieku obserwowano w gospodarce światowej $\mathrm{z}$ jednej strony nadwyżki na rachunku obrotów bieżących $\mathrm{w}$ krajach rozwiniętych gospodarczo, zaś z drugiej strony deficyty na rachunkach obrotów bieżących w krajach transformujących się i rozwijających. Tendencja ta uległa całkowitej zmianie od 1999 roku, kiedy to kraje rozwinięte gospodarczo zaczęły doświadczać rosnących deficytów w bilansach obrotów bieżących, natomiast kraje transformujące się i rozwijające odnotowywały $\mathrm{w}$ tym samym okresie pokaźne nadwyżki na rachunku obrotów bieżacych bilansu płatniczego. Tendencja ta uległa odwróceniu na przełomie 2013 i 2014 roku. Od tego momentu ponownie obserwuje się nadwyżki na rachunkach obrotów bieżących w krajach rozwiniętych gospodarczo oraz deficyty na rachunkach obrotów bieżących w krajach transformujących się i rozwijających. O ile obecnie sytuacja wydaje się być ustabilizowana $\mathrm{w}$ doniesieniu do badanych grup krajów, o tyle zjawisko nierównowag na rachunkach obrotów bieżących jest wciąż istotnym problemem dla wielu pojedynczych gospodarek, w tym dla krajów zaliczanych do tzw. globalnej triady ${ }^{2}$. Również w ramach tej grupy państw można wskazać kraje osiagające ogromne nadwyżki na rachunku obrotów bieżących oraz kraje doświadczające w tym samym czasie chronicznych deficytów w bilansie obrotów bieżących (rys. 2).

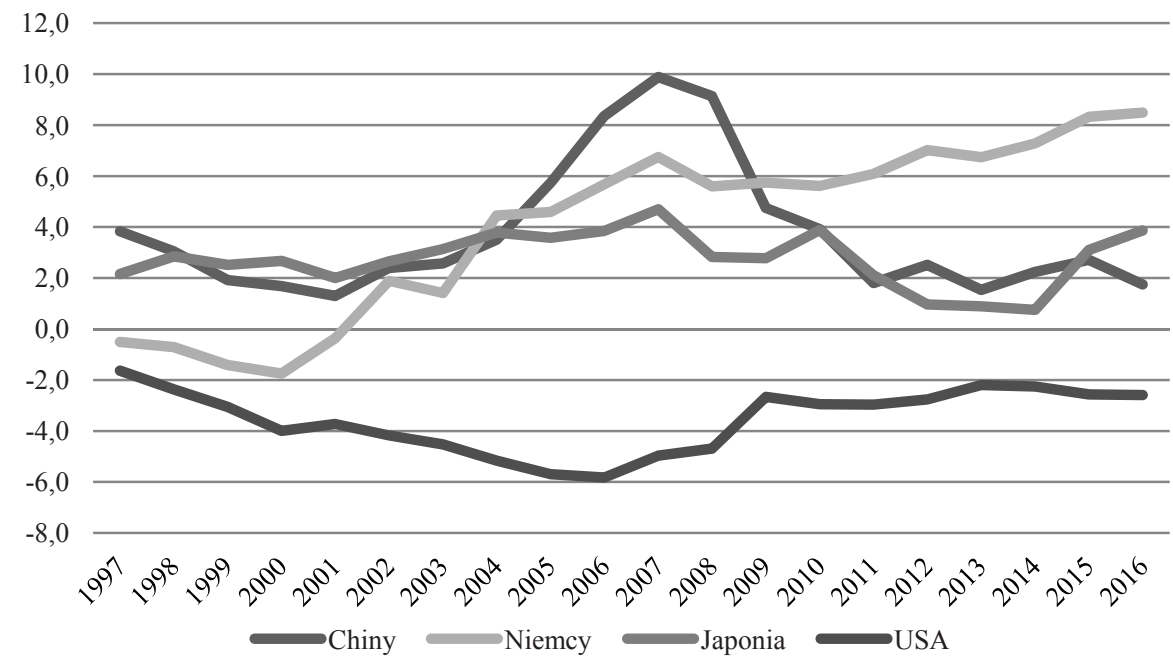

Rys. 2. Udział salda bilansu obrotów bieżących w PKB w wybranych krajach w okresie 1997-2016 (w \%)

Fig. 2. The share of the current account balance in GDP in selected countries in the period 1997-2016 (in \%) Źródło: Opracowanie własne na podstawie (World Economic Outlook, 2017).

Zgodnie z prognozami Międzynarodowego Funduszu Walutowego, problem globalnej nierównowagi $\mathrm{w}$ gospodarce światowej będzie nadal występował $\mathrm{w}$ najbliższych kilku latach, a skala tego problemu będzie wciąż istotna, zarówno dla poszczególnych grup krajów, jak również dla całej gospodarki światowej (rys. 3).

\footnotetext{
${ }^{2}$ Globalna triada - USA, Unia Europejska oraz niektóre kraje azjatyckie (głównie Chiny, Japonia, Indie).
} 


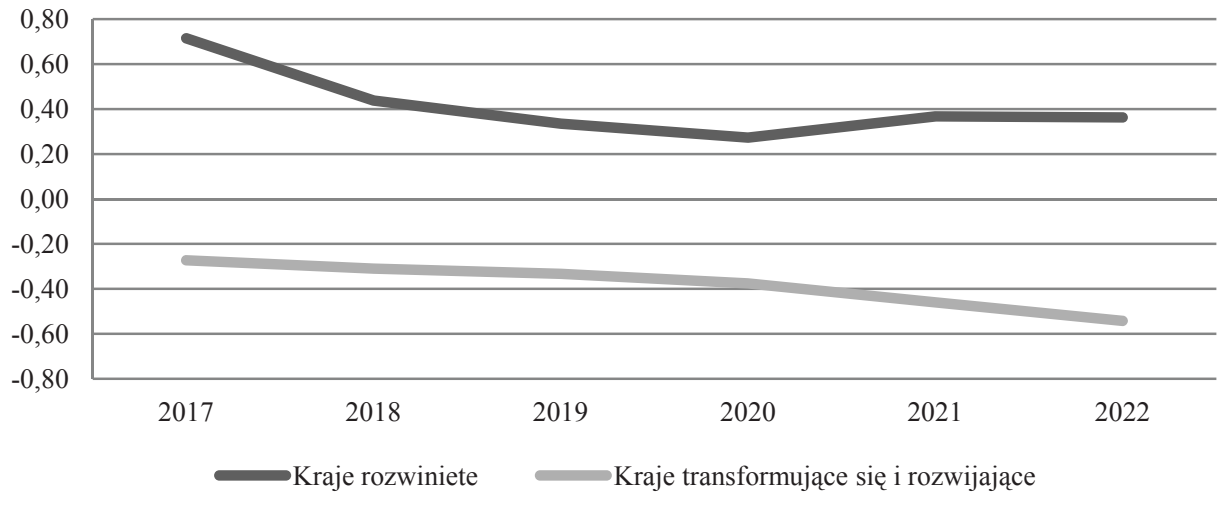

Rys. 3. Prognoza udziału salda bilansu obrotów bieżących w PKB w krajach o różnym poziomie rozwoju gospodarczego w okresie 2017-2022 (w \%)

Fig. 3. Forecast of the share of current account balance in GDP in countries with different levels of economic growth in 2017-2022 (in\%)

Źródło: Opracowanie własne na podstawie (World Economic Outlook, 2017).

Międzynawowy Fundusz Walutowy prognozuje dalsze utrzymanie tendencji rozwojowych obserwowanych w odniesieniu do salda rachunku obrotów bieżących od 2013 roku, przy czym, zgodnie z tymi prognozami sytuacja względnie ustabilizuje się zarówno w krajach rozwiniętych, jak również $w$ krajach transformujących się i rozwijających.

\section{Główne determinanty globalnej nierównowagi finansowej}

W literaturze przedmiotu wskazuje się, że globalna nierównowaga finansowa jest zdeterminowane wieloma czynnikami makroekonomicznymi i finansowymi. Najczęściej ekonomiści wskazują pięć głównych przyczyn istniejących globalnej nierównowagi finansowej we współczesnej gospodarce światowej. Pierwsza z nich związana jest z tzw. hipotezą deficytów bliźniaczych ${ }^{3}$. W tym przypadku przyczyną nierównowagi na rachunku obrotów bieżących jest wysoki poziom deficytu budżetowego w Stanach Zjednoczonych. Druga przyczyną globalnej nierównowagi na rachunku obrotów bieżących jest polityka kursowa prowadzona przez kraje Dalekiego Wschodu zmierzająca do poprawy konkurencyjności cenowej eksportu poprzez deprecjację ich walut. Trzecią przyczyną globalnej nierównowagi jest trwały, długookresowy wzrost wydajności czynników produkcji w Stanach Zjednoczonych, co prowadzi do wzrostu popytu na aktywa amerykańskie. Czwarta przyczyna to nadmierny poziom globalnych oszczędności netto (global saving glut). Wreszcie piątą przyczyną zjawiska globalnej nierównowagi są czynniki instytucjonalne związane z rozwojem sektora finansowego i stopniem otwarcia gospodarek na napływy kapitału zagranicznego.

${ }^{3}$ Zgodnie z hipotezą tzw. deficytów bliźniaczych, deficyt budżetowy prowadzi do pojawienia się deficytu bilansu obrotów bieżących. 
Badania przeprowadzone przez Chinn (2017) ujawniły, iż nierównowagi na rachunkach obrotów bieżących ponownie się pojawiły po światowym kryzysie finansowym, lecz zakres i rozkład tych nierównowag wyraźnie różni się od tych, które odnotowano w połowie ostatniej dekady. Co więcej, wyniki tych analiz pokazały, że czynniki fiskalne stanowią najistotniejsze determinanty obecnych nierównowag finansowych, w szczególności w USA i Niemczech.

Kraje rozwinięte
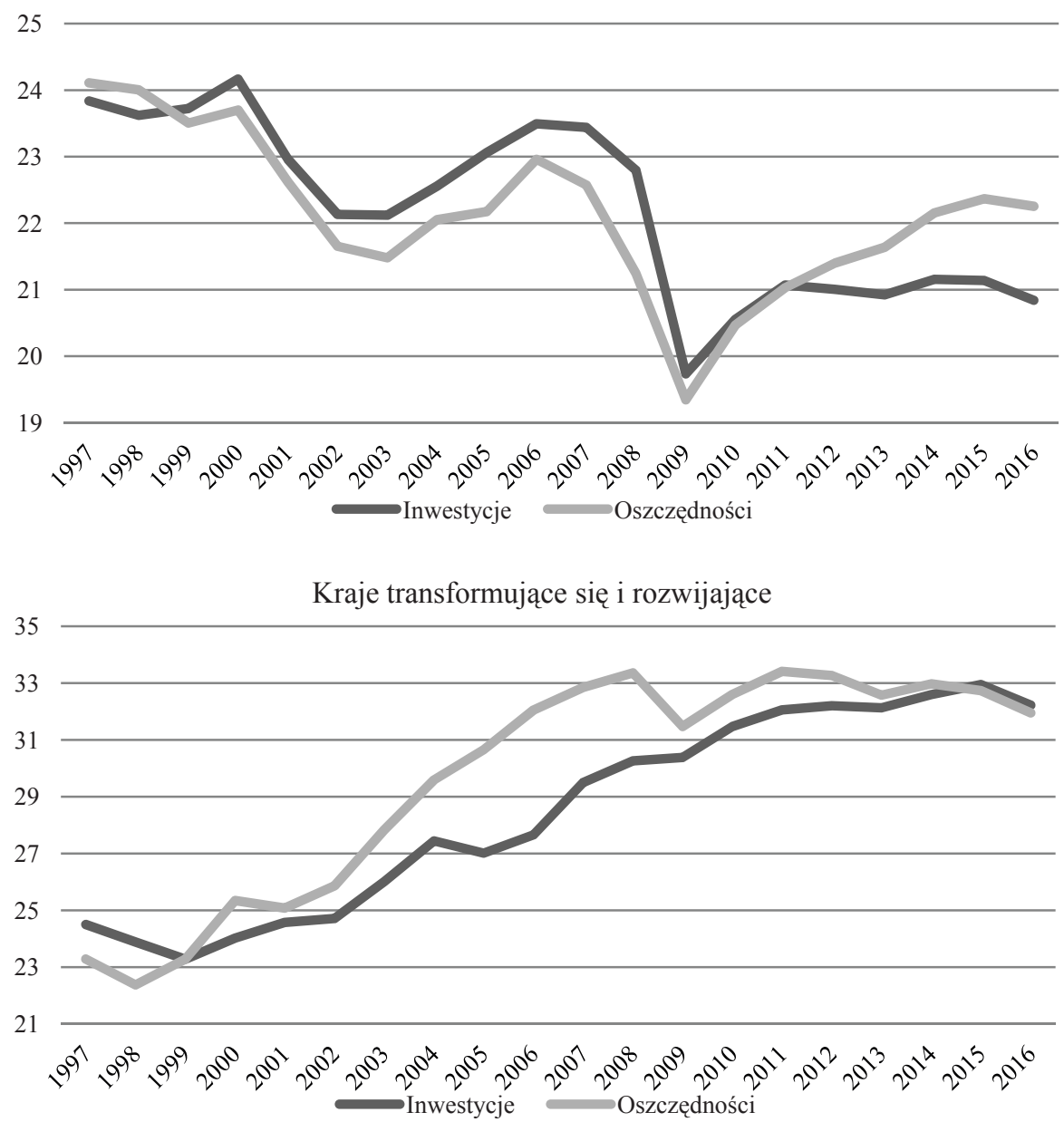

Rys. 4. Stopa inwestycji i stopa oszczędności w krajach rozwiniętych gospodarczo oraz transformujących się i rozwijających w okresie 1997-2016 (w \%)

Fig. 4. Investment rate and saving rate in economically developed countries, transforming and developing in the period 1997-2016 (in \%)

Źródło: Opracowanie własne na podstawie (World Economic Outlook, 2017). 


\section{P. Misztal}

Z kolei, Setser (2016) badając zjawisko globalnej nierównowagi finansowej doszedł do wniosku, że nadmiar oszczędności w Azji Wschodniej przyczynia się do niestabilności finansowej, zarówno w regionie, jak i na całym świecie. Przed kryzysem finansowym nadmiar oszczędności w Azji Wschodniej podsycił bańkę mieszkaniową USA i przyczynił się do powstania wewnętrznej nierównowagi w Stanach Zjednoczonych i strefie euro. Od czasu kryzysu finansowego nadmiar tych oszczędności przyczynił się do powstania baniek spekulacyjnych i złych długów w regionie, zwłaszcza w Chinach.

Chinn i Prasad (2003) badając średniookresowe współzależności między saldem na rachunku obrotów bieżących oraz wybranymi uwarunkowaniami makroekonomicznymi wykazali, że wskaźniki monetyzacji krajów były pozytywnie skorelowane z saldem rachunku obrotów bieżących bilansu płatniczego, w szczególności w krajach rozwijających. Wyniki te są częściowo sprzeczne z wynikami badań przeprowadzonych przez Cheung, Furceri, Rusticelli (2010) którzy potwierdzili występowanie negatywnego wpływu rozwoju sektora finansowego na saldo bilansu obrotów bieżących. Wyniki badań Cheung, Furceri, Rusticelli (2010) zostały potwierdzono również $\mathrm{w}$ analizach przeprowadzonych przez Mendoza, Quadrini, Rios-Rull (2009). Z kolei badania przeprowadzone przez Legg, Prasad i Robinson (2007) ujawniły, iż jedną z przyczyn powstania globalnej nierównowagi jest wysoki poziom oszczędności krajowych $w$ wielu gospodarkach rozwiniętych i rozwijających się. Relacje miedzy stopą oszczędności i inwestycji w krajach rozwiniętych oraz transformujących i rozwijających się przedstawiono na rysunku 4.

Zdaniem Legg, Prasad i Robinson (2007) Stany Zjednoczone w takim układzie występują w roli konsumenta „ostatniej instancji”, tzn. w wyniku wzrostu popytu konsumpcyjnego i inwestycyjnego absorbują wolne środki krajów posiadających nadwyżki finansowe. Nadmierne oszczędności $w$ tych krajach są pochodną realizowanych programów restrukturyzacji przedsiębiorstw krajowych, wzrostu światowych cen ropy naftowej oraz sytuacji społeczno-gospodarczej w tych krajach.

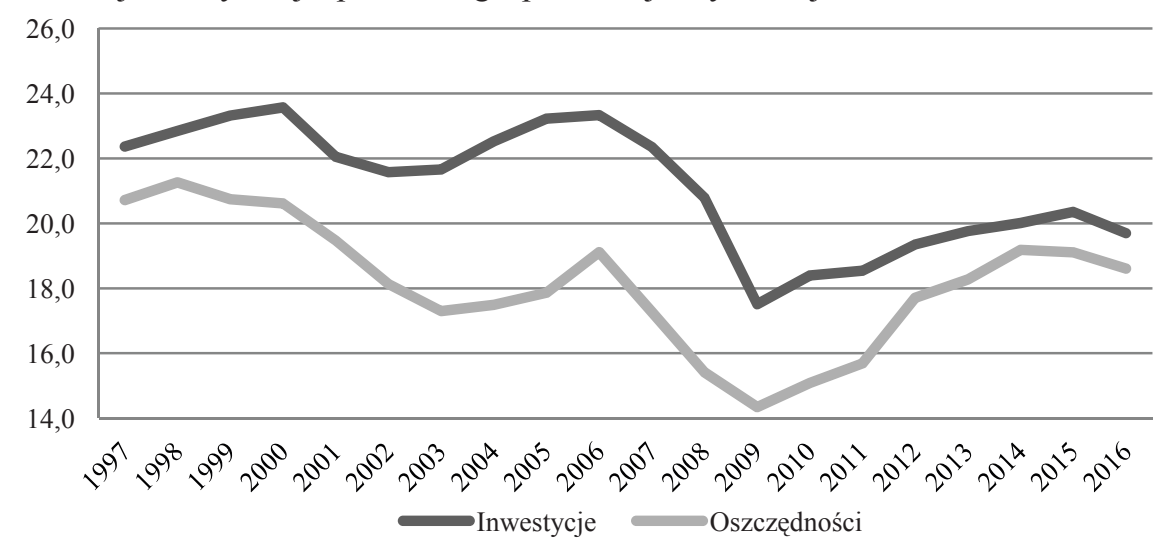

Rys. 5. Stopa inwestycji i stopa oszczędności w USA w okresie 1997-2016 (w \%)

Fig. 5. Investment rate and saving rate in the USA in the period 1997-2016 (in \%)

Źródło: Opracowanie własne na podstawie (World Economic Outlook, 2017).

W szczególności wiele tzw. gospodarek wschodzących odnotowuje systematyczny wzrost oszczędności gospodarstw domowych i przedsiębiorstw w ciagu ostatnich dwóch 
dziesięcioleci doprowadzając do powstania zjawiska nadmiaru oszczędności (Bernanke, 2005). Na przykład w Chinach oszczędności krajowe przekroczyły w 2006 roku 50\% PKB, przy czym udział gospodarstw domowych w całej puli oszczędności krajowych przekroczył 30\%, zaś pozostałą część stanowiły oszczędności przedsiębiorstw (MFW, 2006).

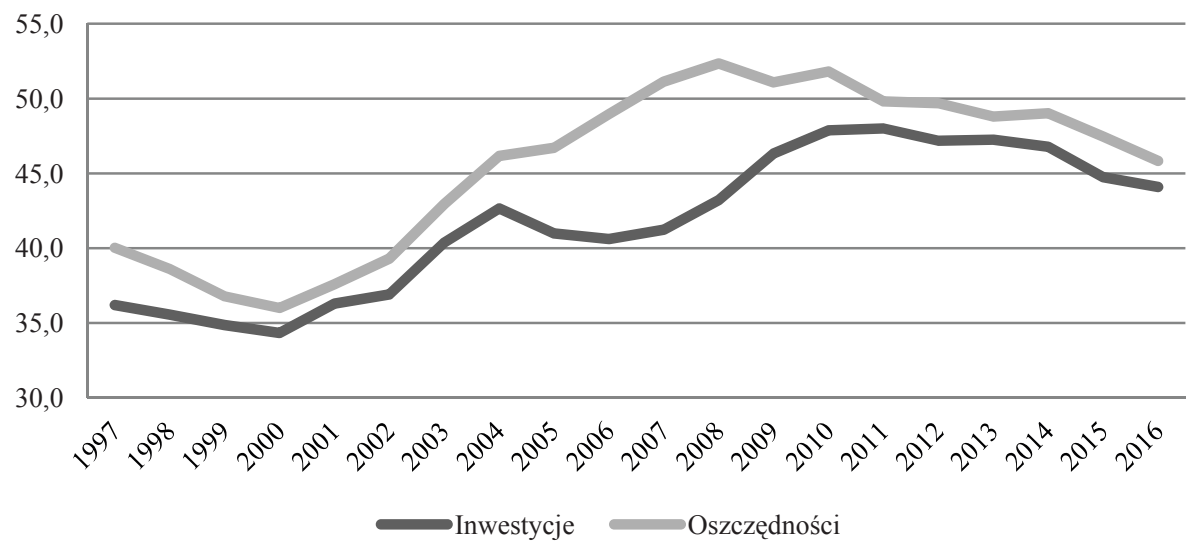

Rys. 6. Stopa inwestycji i stopa oszczędności w Chinach w okresie 1997-2016 (w \%)

Fig. 6. Investment rate and saving rate in China for 1997-2016 (in \%)

Źródło: Opracowanie własne na podstawie (World Economic Outlook, 2017).

Znaczny wzrost oszczędności gospodarstw domowych przynajmniej w części można wyjaśnić występowaniem tradycyjnego efektu Kuznetsa, zgodnie z którym proces rozwoju gospodarczego wypycha dochody biedniejszych gospodarstw domowych poza próg możliwości gromadzenia oszczędności ${ }^{4}$. Z drugiej strony, w tych samych warunkach bogatsze gospodarstwa domowe wciąż powiększają stopę swoich oszczędności. Tym samym pogłębiające się nierówności dochodowe w poszczególnych krajach wpływają na wielkość zagregowanych oszczędności, jednocześnie oddziałując na rachunek obrotów bieżących bilansu płatniczego.

Utrzymaniu globalnej nierównowagi sprzyja także aktywna polityka kursowa prowadzona w szczególności przez kraje azjatyckie. Mianowicie, realny kurs walutowy może być wykorzystywany do osiaggania trwałej nadwyżki na rachunku obrotów bieżących, niezależnie od względnej specjalizacji kraju. Zmiany kursu walutowego mogą być częściowo wynikiem interwencji politycznej, na przykład w krajach, które opierają swój rozwój gospodarczy głównie na eksporcie. W tych krajach konkurencyjne kursy walut maja często kluczowe znaczenie dla stworzenia krótkotrwałego zagregowanego popytu i stworzenia nowych miejsc pracy. Co więcej realne kursy walut istotnie wpływają na zmiany jednostkowych kosztów pracy i stawek płac.

Oprócz wskazanych powyżej wyjaśnień zjawiska globalnej nierównowagi, w literaturze wskazuje się również specyficzne czynniki, które prowadzą do istniejących dysproporcji. Mianowicie, jedną z przyczyn nierównowag na rachunkach obrotów

${ }^{4}$ Zgodnie z hipotezą Kuznetsa zakłada się, że w trakcie rozwoju gospodarczego kraju, nierówności dochodów początkowo rosną zanim ostatecznie zmniejszą się, przybierając graficzną postać odwróconej litery „U”. 
bieżących jest pogłębiająca się integracja gospodarcza i finansowa między krajami oraz postępujący w ślad za tym proces doganiania (catching up) krajów najwyżej rozwiniętych przez kraje o niższym poziomie rozwoju (Belke, Dreger, 2011).

Z kolei, badania przeprowadzone przez Ivanova (2012) wśród krajów rozwiniętych gospodarczo, transformujących i rozwijających się oraz wśród krajów członkowskich Organizacji Współpracy Gospodarczej i Rozwoju (Organization for Economic Cooperation and Development - OECD) wskazują na występowanie pozytywnego wpływu spadku relacji płacy minimalnej $\mathrm{w}$ stosunku do średniego wynagrodzenia oraz stopnia protekcji na rynku pracy na saldo rachunku obrotów bieżących. $Z$ drugiej strony, badania ujawniły negatywne oddziaływanie deregulacji na rynku finansowym, redukcji podatków i uproszczeń podatkowych na bilans obrotów bieżących.

\section{Sposoby ograniczenia zjawiska globalnej nierównowagi finansowej}

Nierównowagi zewnętrzne krajów nie stanowią problemu jeśli odzwierciedlają efektywną realokację oszczędności pomiędzy krajami nadwyżkowymi i deficytowymi. Globalizacja i integracja rynków finansowych mogą ułatwić przepływ oszczędności z krajów nadwyżkowych do krajów deficytowych, co jest zjawiskiem pozytywnym, gdyż prowadzi do efektywniejszej alokacji kapitału. Kraje posiadające deficyt na rachunku obrotów bieżących mogą skorzystać z oszczędności zagranicznych by sfinansować krajowe inwestycje napędzające wzrost gospodarczy. Tym samym inwestorzy $z$ krajów posiadających nadwyżki na rachunku obrotów bieżących mogą osiagnąć wyższe stopy zwrotu z inwestycji w krajach deficytowych. Te współzależności prowadzą do większej efektywności kapitału i szybszego globalnego wzrostu gospodarczego. Jednakże w sytuacjach, gdy nierównowagi na rachunkach obrotów bieżących osiąają nadmierne (trudne do udźwignięcia) poziomy, wówczas nierównowagi zewnętrzne są postrzegane jako jeden z czynników przyczyniających się do powstawania kryzysów gospodarczych. Stąd w literaturze przedmiotu wskazuje się na konieczność podjęcia odpowiednich działań zmierzających do wyeliminowania problemu globalnej nierównowagi w gospodarce światowej.

Po pierwsze, konieczne wydaje się ograniczenie zagregowanego popytu krajowego w USA w celu ograniczenia importu i jednoczesnego wsparcia eksportu. Po drugie, niezbędne jest stworzenie zachęt do wzrostu konsumpcji w Azji i na Bliskim Wschodzie oraz uelastycznienie kursu walutowego w Chinach. Po trzecie, konieczne jest przeprowadzenie reform strukturalnych w Europie Zachodniej w celu zwiększenia potencjału do szybszego wzrostu gospodarczego (El-Erian, 2008).

Zdaniem Eichengreena (2011) Chiny w niedalekiej przyszłości wzmocnią międzynarodową pozycję juana przez wprowadzenie pełnej wymienialności waluty, rozwój płynnych rynków finansowych oraz liberalizację dostępu do tych rynków. Jego zdaniem, Juan stanie się główną walutą rezerwową po 2030 roku, co przyczyni się do ograniczenia problemu globalnej nierównowagi. Do tego czasu będą istnieć trzy waluty międzynarodowe, tzn. dolar, euro oraz jen.

Z kolei Mundell (2010) proponuje oparcie międzynarodowego systemu walutowego na parze euro-dolar, co wyeliminuje wzajemne wahania kursów tych walut. Koszyk walutowy „globalnej” waluty może być poszerzony w przyszłości o funta szterlinga, franka 
szwajcarskiego, jena czy juana, co ustabilizuje sytuację na międzynarodowych rynkach finansowych i przyczyni się do ograniczenia skali globalnej nierównowagi.

Podobnie Mateos y Lago, Duttagupta i Goyal (2009) proponują odejście od systemu jednej dominującej waluty na rzecz koszyka walut, co zmusi główne kraje świata do współpracy finansowej i zarazem będzie przeciwdziałać powstawaniu i pogłębianiu się globalnej nierównowagi.

Alternatywnym rozwiązaniem wobec systemu opartego na koszyku walut prowadzącym do ograniczenia zjawiska globalnej nierównowagi może być zdaniem Subacchi (2010) dążenie zwiększenie roli Specjalnych Praw Ciągnienia (Special Drawing Rights - SDR) w roli waluty międzynarodowej. Wykorzystanie SDR opartego o najsilniejsze waluty może ułatwić zarządzanie rezerwami walutowymi, ograniczyć konieczność tworzenia portfela wielowalutowego oraz rozszerzyć korzyści z tytułu emisji waluty międzynarodowej na wszystkie kraje, których waluty tworzą koszyk SDR.

Również działalność Światowej Organizacji Handlu (World Trade Organization$W T O)$ może pomóc w zmniejszeniu problemu globalnej nierównowagi poprzez działania prowadzące do większego otwarcia krajów w handlu usługami oraz w obszarze zamówień publicznych. Liberalizacja handlu usługami może pomóc w rozwiązaniu niektórych problemów strukturalnych, przyczyniających się do nagromadzenia się nadwyżek na rachunku obrotów bieżących. Ponadto, wiele krajów z dużym deficytem obrotów handlowych, ma znaczące nadwyżki w handlu usługami, co w sytuacji większej liberalizacji usług może pomóc w zrównoważeniu rachunku obrotów bieżących.

\section{Zakończenie}

Zgodnie z przyjętym celem artykułu, analizowano w niniejszej pracy skalę problemu globalnej nierównowagi finansowej we współczesnej gospodarcze światowej, z jednoczesnym wskazaniem głównych czynników determinujących to zjawisko. Na podstawie przeprowadzonych badań literaturowych, stwierdzono, że do najważniejszych determinant tego zjawiska można zaliczyć nadwyżkę globalnych oszczędności, prowadzoną politykę merkantylistyczną w krajach Azji Wschodniej oraz pogłębiające się procesy integracji gospodarczej.

Rezultaty przeprowadzonych badań mają ogromne znaczenie w szczególności z makroekonomicznego punktu widzenia, bowiem zjawisko globalnej nierównowagi sprawia ogromne zaburzenia w pojedynczych krajach i grupach krajów. Mianowicie, ogromne nadwyżki lub deficyty na rachunkach obrotów bieżących wywołują chroniczne nadwyżki lub deficyty w budżetach krajowych poprzez tzw. efekt deficytów bliźniaczych. Dodatkowo nierównowagi na rachunkach obrotów bieżących wpływają na międzynarodową pozycję konkurencyjną gospodarek, ceny towarów, usług, walut i czynników produkcji.

Nierównowagi na rachunkach obrotów bieżących mogą być problematyczne szczególnie w przypadku krajów deficytowych. Rosnące deficyty zwiększają ryzyko „,nagłego zatrzymania", czyli zmiany nastrojów inwestorów. Chodzi o sytuację, gdy inwestorzy z różnych względów (np. ze względu na zbyt wysokie ryzyko inwestowania w danym kraju) nagle nie chca finansować deficytu obrotów bieżących danego kraju. Międzynarodowe powiązania gospodarek i słabe transgraniczne procesy rozwiązywania 
problemów banków i instytucji finansowych oznaczają że sytuacja „nagłego zatrzymania” może szybko przerodzić się w problemy globalne.

Dlatego też, znając główne czynniki determinujące zjawisko globalnej nierównowagi finansowej jest możliwe skonturowanie takiego programu działań, który ograniczy, bądź całkowicie wyeliminuje to zjawisko we współczesnej gospodarce światowej.

\section{Literatura}

Belke, A., Dreger, Ch. (2011).Current Account Imbalances in the Euro Area: Catching Up or Competitiveness? DIW Discussion Papers, 1106.

Bernanke, B. (2005). The Global Saving Glut and the U.S. Current Account Deficit. Paper presented at the Homer Jones Lecture, St. Louis, Missouri, April 14.

Cheung, C., Furceri, D., Rusticelli, E. (2010). Structural and Cyclical Factors Behind Current Account Balances. Paris: Organization for Economic Cooperation and Development (OECD).

Chinn, M.D. (2017). The Once and Future Global Imbalances? Interpreting the Post-Crisis Record. Paper presented at the Jackson Hole conference, August.

Chinn, M.D., Prasad, E. (2003). Medium-Term Determinants of Current Accounts in Industrial and Developing Countries: an Empirical Exploration. Journal of International Economics, 59(1), 47-76.

Eichengreen, B. (2011). The Renminbi as an International Currency. Journal of Policy Modeling, 33(5), 723-730.

El-Erian, M. (2008). How Best to Manage Global Imbalances. Financial Times, June 16.

IMF (2006), World Economic Outlook, Oil Prices and Global Imbalances, April, IMF, Washington D. C.

Ivanova, A. (2012). Current Account Imbalances: Can Structural Policies Make a Difference? IMF Working Paper, 61 .

Legg, A., Prasad, N., Robinson, T. (2007). Global Imbalances and the Global Saving Glut - A Panel Data Assessment. Reserve Bank of Australia Research Discussion Paper, 11.

Mateos y Lago, I., Duttagupta, R., Goyal, R. (2009). The Debate on the International Monetary System. International Monetary Fund Staff Position Note, November 11

Mendoza, E.G., Quadrini, V., Rios-Rull, J. (2009). Financial Integration, Financial Deepness and Global Imbalances. Journal of Political Economy, 117(3), 371-416.

Mundell, R. (2010). Shaping the Future of the International Monetary System. Paper presented on conference. National Bank of Poland, Warsaw, May 26.

Setser, B. (2016). The Return of the East Asian Savings Glut. Council for Foreign Relations Discussion Paper, October.

Subacchi, P. (2010). Introduction: No New Bretton Woods, but a System in Flux in: Beyond the Dollar, Rethinking the International Monetary System. eds. P. Subacchi, J. Driffill, Institute for International Affairs, Chatham House, London.

World Economic Outlook (2017). International Monetary Fund, Washington.

Do cytowania / For citation:

Misztal P. (2018). Globalna nierównowaga finansowa we współczesnej gospodarce światowej.

Problemy Rolnictwa Światowego, 18(1), 149-158; DOI: 10.22630/PRS.2018.18.1.14

Misztal P. (2018). Global Financial Imbalance in the Contemporary World Economy (in Polish).

Problems of World Agriculture, 18(1), 149-158; DOI: 10.22630/PRS.2018.18.1.14 